\title{
Diversity of Soil Arthropods in Teak Plantation Forests at Cepu, Blora, Central Java
}

\author{
Noor Farikhah Haneda ${ }^{1 *}$, Novia Tri Marfuah ${ }^{2}$ \\ ${ }^{1}$ Department of Silviculture, Faculty of Forestry, Bogor Agricultural University, Academic Ring Road, Campus IPB Dramaga, \\ PO Box 168, Bogor 16680, Indonesia \\ ${ }^{2}$ Forest Utilization Unit XI, Ir. Pangeran M. Noor Street, Banjarbaru, 70714, Indonesia
}

Received January 14, 2013/Accepted November 7, 2013

\begin{abstract}
Insects are the main group of soil arthropod and the most dominant animals in the terrestrial ecosystems. The aims of this study were to get information about soil arthropod diversity in relation to environmental influence at teak plantations at Cepu, Central Java. The sampling plot design was based on forest health monitoring design method. Pitfall trap and Berlese-Tullgren funnel were employed to collect the soil arthropods. The trapped specimens were sorted in the laboratory and then identified up to family or genus. The result of the study revealed that young-age plantation has higher abundance and diversity of arthropod than old-age plantation. Totally we found 3 classes, 11 orders, 29 families, and 714 individuals from young teak plantation, and 3 classes, 11 orders, 25 families, and 397 individuals from the old one. The dominant class was insect and the dominant order of the insects was Hymenoptera. The thickness of the teak litter was the most important factor to the abundance of soil arthropods $\left(R^{2}=0.891\right)$.
\end{abstract}

Keywords: forest health monitoring, environmental factor, teak litter, pitfall, Berlese-Tullgren funnel

\begin{abstract}
Abstrak
Serangga merupakan kelompok binatang terbesar dari arthropoda tanah dan paling dominan di ekosistem terestrial. Tujuan penelitian ini adalah untuk mendapatkan informasi hubungan keanekaragaman artropoda tanah dengan pengaruh lingkungan di hutan hutan jati di Cepu, Jawa Tengah. Plot pengamatan dibuat berdasarkan desain forest health monitoring. Metode Pitfall trap dan Corong Berlese-Tullgren digunakan untuk mengoleksi arthropoda tanah. Pemisahan hasil koleksi dilakukan di laboratorium dan kemudian diidentifikasi sampai tingkatan famili atau genus. Hasil penelitian menunjukkan bahwa hutan jati umur muda (kelas umur III) mempunyai kelimpahan dan keanekaragaman arthopoda tanah yang lebih tinggi dibandingkan dengan hutan jati umur tua (kelas umur VI). Secara keseluruhan didapatkan 3 kelas, 11 ordo, 29 famili, dan 714 individu di hutan jati umur muda, sedangkan di hutan jati umur tua didapatkan 3 kelas, 11 ordo, 25 famili, dan 397 individu. Kelas yang dominan dari kelompok arthropoda adalah serangga, sedangkan ordo yang dominan adalah Hymenoptera. Ketebalan serasah merupakan faktor yang penting dalam hubungannya dengan kelimpahan arthropoda tanah $\left(R^{2}=0.891\right)$.
\end{abstract}

Kata kunci: forest health monitoring, faktor lingkungan, serasah, pitfall, corong Berlese-Tullgren

*Correspondence author, email:nhaneda@yahoo.com, tel.: +62-251-8626806

\section{Introduction}

The great number of species interacted with complexity of food chain are the reason for stable ecosystem because food chain is a complex balance of life. However, in recent years, human activities, like forest logging, conversion of natural forests to a plantations forest, and other disturbance to the forest have caused instability of the ecosystem. The issues of forest destruction, forest fragmentation, biological conservation, and ultimately sustainable management of tropical forest have attracted the attention of biologists all over the world. The great number of species and the value to the biosphere are reason for their fascination to biologists.
Forest disturbances cannot be avoided as development requires a certain amount of land clearance. However, there must exist a balance between preservation and utilization of the forest. A concerted effort toward conservation is therefore highly warranted. The critical fauna's habitat such as lowland forest in the tropic is raidly diminishing particularly in the developing country. Thus, a thorough understanding of landscape quality is essential for monitoring forest environmental changes, and that its impact towards animals, expecially soil arthropods are urgently needed.

At the present time many people want to know 
biodiversity that explain the variability of species of the organisms. Biological diversity, very simply, refers to all of the different kinds of life on earth. Diversity is a simple concept. In ecology, it means variety. Biodiversity is used as a synonym for the variety of life. Gaston (1996) defines biodiversity as the structural and functional variety of life forms at genetic, species, population, community, and ecosystem levels.

Soil arthropod is one of the terrestrial organisms. Insects and other arthropods are abundant throughout terrestrial ecosystems. They apparently consumed about $20 \%$ of the foliage annually worldwide. They are in association with many other detritivore invertebrates, fungi and bacteria in releasing and recycling the nutrients that are fixed in decaying vegetation (Samways 1994; Abbott et al. 2002).

It has been recognized that there are different biodiversity and abundance of organisms among different habitats but the difference has not yet been thoroughly investigated. The abundance of a species is influenced by several environmental (biotic and abiotic) factors (Detsis et al. 2000; Jukes et al. 2001). It is reasonable to conduct a study to describe species diversity in a certain habitat and try to find out which environmental factors play an important role in determining the abundance of the existing organisms, especially the soil arthropods (Bonham et al. 2002; Pflug \& Wolters 2002). The objectives of the study were to investigate the difference between soil arthropod diversity living in a younger teak plantation and in an older one in Cepu Forest District and determine the most influencing environmental factor influencing the abundance of soil arthropods. The study is expected to provide a considerable benefit to for stakeholders in the process of monitoring the soil nutrition and in management of teak plantation forest.

\section{Methods}

The research was conducted at teak forest plantation whitin the forest health monitoring (FHM) plots in Cepu. The sampling plot was located in 2 different age classes of teak plantation. Age class is a distinct aggregation of tress originating from a single natural or regeneration activity, or a grouping of trees, eg. 10-year age class, as used in teak plantation (Helms 1998). The locations of sampling plots were at the compartment 1039 (age class III-young) at Pasarsore Sub Forest District and compartment 4005 (age class VI-old) at Cabak Sub Forest District, Cepu Forest District.

Sampling plots were choosen by referencing to FHM plot (Figure 1). The plots had been pre-prepared by the previous research team. Based on FHM method, the determination of sampling plots was prepared using cluster plot design. One cluster within the sampling plot consisted of 4 sub-plots or annular plots. Every plot had a radius of $7.32 \mathrm{~m}$ for a subplot and $17.95 \mathrm{~m}$ for annular plot. The center of the subplot 1 was the center for all the plots. The center of subplot 2 lied at the azimuth $360^{\circ}$ from the center of subplot 1 and the distance was $36.6 \mathrm{~m}$. The center of subplot 3 lied at the azimuth $120^{\circ}$ from the center of subplot 1 and the distance was $36.6 \mathrm{~m}$. The center of subplot 4 lied at the azimuth $240^{\circ}$ from the center of subplot 1 and the

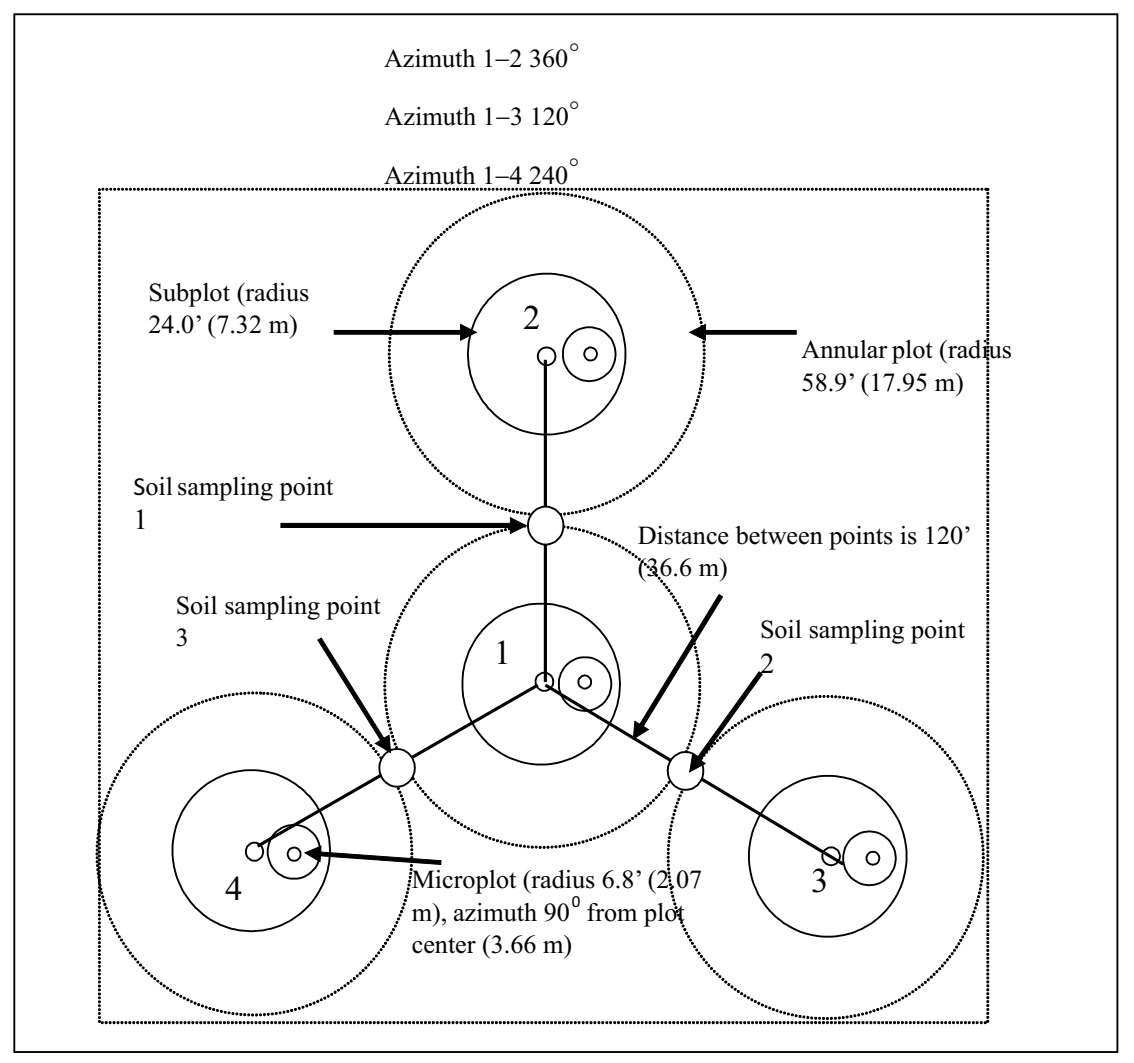

Figure 1 Forest health monitoring (FHM) plot design (O ) = Trapping plot of soil arthropod (Alexander 1997). 
distance was $36.6 \mathrm{~m}$. Soil samples were taken from 3 points, circular in shape, lied between subplot 1-2, subplot 2-3, and subplot 1-4 with a hole diameter of $16 \mathrm{~cm}$. Observation of soil arthropods was conducted on the holes lying beside soil sample plots. Observation plots for soil arthropods using Berlese-Tullgren funnel were made with the size $50 \times 50 \mathrm{~cm}$, $5 \mathrm{~cm}$ depth from the litter surface. The dish for pitfall trap method was set at observation plot of $1 \times 1 \mathrm{~m}$ in size. The trapped soil arthropods were collected placed in alcohol $70 \%$ within film tubes and labelled according to the number of observation plots.

This Pitfall trap was employed following Ward et al. (2001) with some modification. The Pitfall trap trapped which is a plastic glasses half filled with $70 \%$ alcohol was immersed as deep as $1.5-2 \mathrm{~cm}$ into the soil with the lips of the glasses were parallel to the soil surface, and left for a week after which specimens were collected and brought back to laboratory. A total of 5 traps were installed per plot with $1 \mathrm{~m}$ separating between them.

The Berlese-Tullgren funnel method was used to extract soil arthropods which live in the soil. The method is applied in 2 stages, firstly the separation of the arthropods from the litter layer and secondly the separation of arthropods from the soil layer up to the depth of $0-5 \mathrm{~cm}$. The Barlese-Tullgren funnel method was applied by taking samples of litter and soil and then the samples were placed in funnels. This extractor used a heat source (electric lamp) set on the top of the funnel so that the arthropods would be forced to move downward and fell down to the collection bottle set beneath the extractor.

The environmental factors to be measured were air temperature and humidity, soil $\mathrm{pH}$, cation exchange capacity, abundance of trees and understorey, diversity of trees and understorey, and litter thickness. Soil arthropods were identified based on morphology characters following (Goulet \& Huber 1993; Borror et al. 1996; Bolton 1997; Deelman-Reinhold 2001; Jocque \& Dippenaar-Schoeman 2005).

The data on were analyzed using Species Richness Biodiversity Programme and GW-BASIC 3.20 (Ludwig \& Reynolds 1988) to determine richness index, diversity index, and evenness index. Abundance of soil arthropod speciess and environmental factors were analysed using regression analysis on SPSS Program version 13.0.

The formulas to be used were as shown in Equation [1], [2], and [3]

Richness index:

$D M g=\frac{(S-1)}{\ln N}$

note:

$D M g$ = Margalef's index of richness,

$S \quad=$ number of species found

$N=$ the number of individual of the total species

Dmg value $<3.5$ indicated that the species richness is low, $\mathrm{DMg}$ value between 3.5-5.0 indicated that the species richness is medium, and $\mathrm{DMg}$ value $>5.0$ indicated that the species richness is high (Magurran 1988).
Diversity index:

$$
\begin{aligned}
H^{\prime} & =-\sum P_{i} \ln P_{i} \\
P_{i} & =\frac{n_{i}}{N}
\end{aligned}
$$

note:

$H^{\prime} \quad=$ Shannon-Weiner's index of diversity

$P_{i} \quad=$ fraction of the entire population made up of species

$n_{i} \quad=$ the number of individual of certain $\left(i^{\text {th }}\right)$ species

$N \quad=$ the number of individual of all species

Evenness index:

$E=\frac{N_{2}-1}{N_{1}-1}$

note:

$E \quad=$ evennes index

$N_{2} \quad=$ abundance value

$N_{2}=e^{\mathrm{H}^{\prime}}$

$N_{l}=$ the abundance value of the species within the sample

Alatalo (1981) recognized that the $\mathrm{E}$ value would approach zero if one species become more dominant in the community.

\section{Results and Discussion}

Pitfall trap method The number of individuals of the order Hymenoptera was the highest at the 2 study areas (Cepu Age Class III and Cepu Age Class VI) with the number of individuals was 411 and 126, respectively (Figure 2). The Formicidae was the most dominant in the order Hymenoptera. More clearance for forest age class III may made the number of Formicidae collected was higher than the other forest. This may be due to the diversity of understorey plants provides the shelter and food for ants (Maschwitz et al. 1996; Bluthgen et al. 2000). Change in plant composition in this habitat might initiate ant colonization (Renata \& Cerda 2000; Malsch et al. 2003). Age class III has abundant understorey because of the high light penetration to the forest floor (Jukes et al. 2001). Moreover, Hymenopterans may also more abundant in age class III because they were visiting the numerous existing flowers (Idris \& Nor-Zaneedarwarty 2000; Hill et al. 2001; Idris \& Hainidah 2003).

Berlese-Tullgren Funnel method The Berlese-Tullgren funnel also showed that order Hymenoptera was the most dominant at the 2 study areas (Cepu Age Class III and Cepu Age Class VI), with number of individuals was 50 and 52, respectively (Figure 3).

Total soil arthropods The abundance of all soil arthropods in the young teak plantation (compartment 1039) was higher than that of the old teak plantation (compartment 4005) (Figure 4).

In Cepu Age Class III and Cepu Age Class VI the most abundance anthropods was the hymenopterans with 461 and 178 individual, respectively. In the young teak plantation, the arthropods consisted of 11 order within 3 classes, having the abundance of 714 individuals within 37 families. In old 


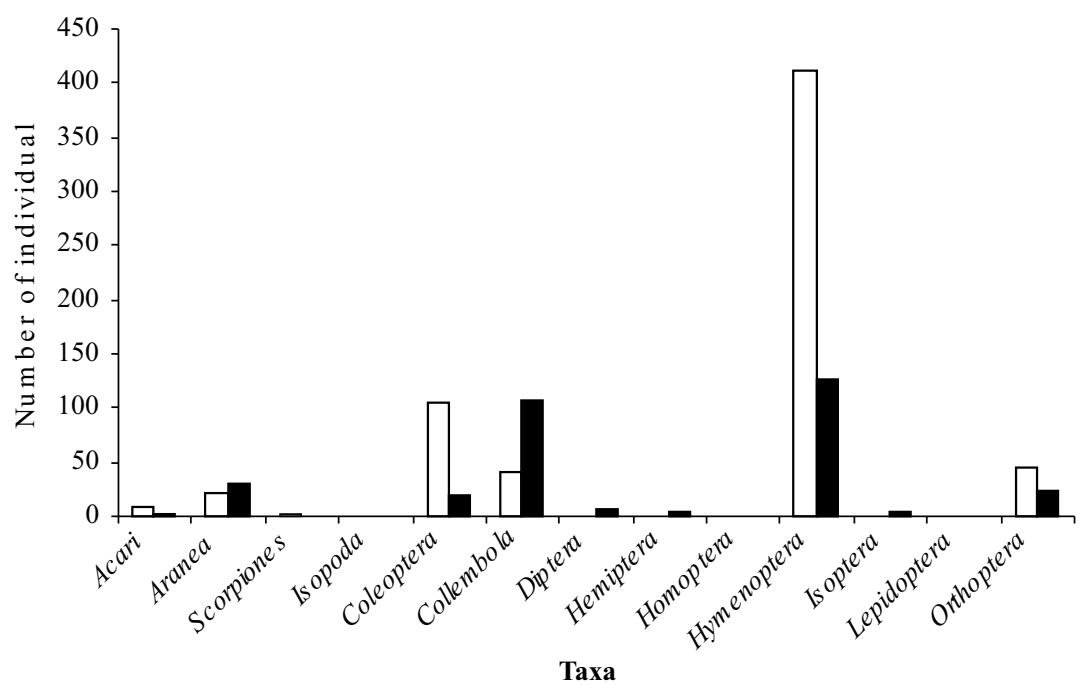

Figure 2 The abundance of soil arthropods using pitfall trap method. Age class III ( $\square$ ), age class VI ( $\square$ ).

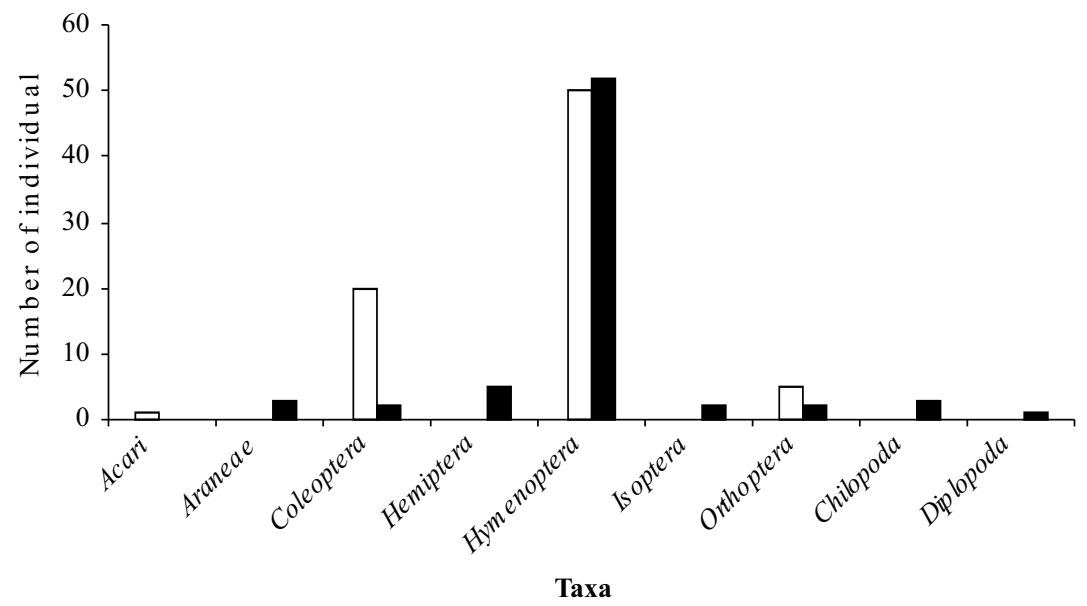

Figure 3 The abundance of soil arthropods using Berlese-Tullgren method. Age class III ( $\square$ ), age class VI (ם).

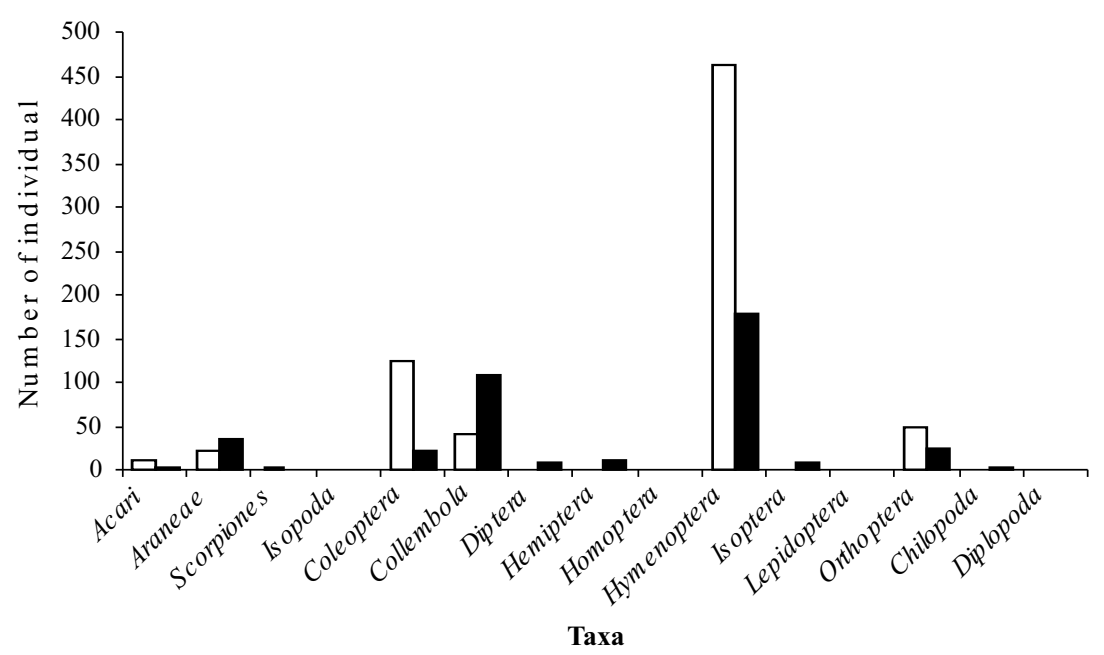

Figure 4 The abundance of all soil arthropods in the 2 study areas. Age class III ( $\square$ ), age class VI ( $\square$ ). 
teak plantation, the arthropods consisted of 11 order within 3 classes with 397 individuals within 26 families (Table 1). There was only 1 individual of the Isopoda, the order of Diptera, Homoptera, and Lepidoptera belong to the class of Insecta (young teak plantation), and the class Diplopoda in the old teak plantation). There was only 1 individual of the Isopoda, the order of Diptera, Homoptera, and Lepidoptera belong to the class of Insecta (young teak plantation), and the class Diplopoda in the old teak plantation.

The younger teak plantation had a higher composition

Table 1 The number of individual in family level of insect

\begin{tabular}{|c|c|c|c|c|}
\hline \multirow{2}{*}{ Class } & \multirow{2}{*}{ Order } & \multirow{2}{*}{ Family } & \multicolumn{2}{|c|}{ Location } \\
\hline & & & Cepu age class III & Cepu age class VI \\
\hline \multirow[t]{5}{*}{ Arachnida } & Acari & & 10 & 3 \\
\hline & Araneae & Lycosidae & 3 & 10 \\
\hline & & Pisauridae & 14 & 19 \\
\hline & & Segestriidae & 5 & 5 \\
\hline & Scorpiones & Scorpionidae & 2 & 0 \\
\hline Crustacea & Isopoda & Trichoniscidae & 1 & 0 \\
\hline \multirow[t]{33}{*}{ Hexapoda } & Coleoptera & Carabidae & 1 & 1 \\
\hline & & Halticidae & 8 & 1 \\
\hline & & Histeridae & 2 & 0 \\
\hline & & Lyctidae & 24 & 0 \\
\hline & & Mordellidae & 4 & 0 \\
\hline & & Mycetophagidae & 0 & 0 \\
\hline & & Nitidulidae & 29 & 2 \\
\hline & & Phalacridae & 1 & 0 \\
\hline & & Salpingidae & 1 & 0 \\
\hline & & Scarabaidae & 36 & 5 \\
\hline & & Scolytidae & 6 & 0 \\
\hline & & Scydmaenidae & 0 & 1 \\
\hline & & Staphylinidae & 12 & 12 \\
\hline & Collembola & Entomobrydae & 32 & 86 \\
\hline & & Puduridae & 2 & 0 \\
\hline & & Pseudochorutidae & 7 & 21 \\
\hline & Diptera & Chamaemyiidae & 0 & 1 \\
\hline & & Piophilidae & 1 & 0 \\
\hline & & Phoridae & 0 & 4 \\
\hline & & Sciaridae & 0 & 2 \\
\hline & Hemiptera & Cimicidae & 0 & 2 \\
\hline & & Lygaeidae & 0 & 3 \\
\hline & & Reduviidae & 0 & 5 \\
\hline & & Thyphlocybinae & 1 & 0 \\
\hline & Hymenoptera & Formicidae & 459 & 176 \\
\hline & & Mymaridae & 0 & 2 \\
\hline & & Tiphiidae & 2 & 0 \\
\hline & Isoptera & Termitidae & 0 & 7 \\
\hline & Lepidoptera & Larvae & 1 & 0 \\
\hline & Orthoptera & Acrididae & 1 & 0 \\
\hline & & Gryllidae & 40 & 15 \\
\hline & & Tetrigidae & 5 & 0 \\
\hline & & Grillacrididae & 4 & 10 \\
\hline \multirow[t]{2}{*}{ Myriapoda } & Chilopoda & Cryptopidae & 0 & 3 \\
\hline & Diplopoda & Spirobolidae & 0 & 1 \\
\hline
\end{tabular}


and abundance of soil arthropods compared to the older teak plantation. This may be due to the availability of food source, in a younger teak plantation are as it has higher tree density, compared to that of the older plantation (Barbosa \& Marquet 2002; Warren \& Zou 2002). Besides, the monoculture plantation (pure stand) also provided a better condition to support the life of a certain arthropod especially food and habitat (Toft et al. 2001; Warren \& Zou 2002). This condition was supported by the fact that the arthropods found in the young plantation (compartment 1039) were more abundant than that of the old one (compartment 4005). In the younger plantation the trees consist of only the teak (Tectona grandis), and in the older one consisted of teak (T. grandis), ploso (Butea monosperma), and Dalbergia latifolia. Simplification of the forest structure and loss of major competitive species have enabled some species to survive and dominant in the disturbed habitat (Majer \& Nichols 1998; Strehlow et al. 2002).

Beside the environmental factors, the characteristic of arthropod (such as way of life and feeding) also has an important role to the presence of the arthropods in a certain habitat (Pflug \& Wolters 2002). In the 2 study areas, the most abundant arthropod was from the order Hymenoptera, especially the family Formicidae (ant). The teak forest in Cepu Forest District had suffered forest fires. DeBano et al. (1998) explained that the ant population on the burnt site would increase due to many seeds to be eaten. Formicidae is also a hymenopteran group that easy to find and disperse in large areas (Borror et al. 1996; Gandhi et al. 2001).

The diversity of arthropods in Cepu Age Class III was higher than that in Cepu Age Class VI (Table 2). The DMg, $\mathrm{H}^{\prime}$ and $\mathrm{E}$ values in Cepu Age Class III were 5.479, 2.672, and 0.635 , respectively. Generally, the richness, diversity, and evenness indexes were higher in younger plantation than in the older one. This was due to the undergrowth species (Jukes et al. 2001). Bird et al. (2000) found that species diversity was higher in the first year following removal of trees. Arthropod species richness increased following nitrogen and phosphorus application. This indicates that the arthropod community had responded to fertilizer application with a change in community composition. Finch (2005) also suggested that spider diversity was significantly higher in the spruce forest (55 years old), compared to the beech (170 years old) and pine stand (110 years old), respectively.

The arthropod species in compartment 1039 and 4005 distributed evenly throughout the area. This was indicated by the evenness index in each study area which was higher than zero. The evenness of the species was supported by the condition of habitat in each area for example (the availability of food sources for the arthropods life) (Detsis et al. 2000; Manh \& Nguyen 2000; Magura 2002) and the characteristic of the arthropods themselves (such as life style and feeding).

The evenness index in the younger plantation was higher than that in the older one. This was due to the occurrence of forest disturbances in each location (such as forest fires and human activities), which could make one species of arthropod in a location is more dominant than the others (Orendt 2000; Zhu et al. 2000; Dombos 2001; SiiraPietikainenm et al. 2001; Strehlow 2002; Siira-Pietikainenm etal.2003).

Relation between arthropods abundance and environmental factors Regression analyses showed that among the environmental factors measured, the litter thickness was found to be the most significant factor $(F=$ 57.35, $r=0.89, d f=1 \& 7, P<0.01)$ influencing the number of arthopods collected than due to other factor (number of tree species diversity and the number and diversity of undergrowth) (Table 3).

So, it could be concluded that food (litter) was the

Table 2 Diversity index, richness index, and evenness index of soil arthropods in the 2 study areas

\begin{tabular}{lcc}
\hline & \multicolumn{2}{c}{ Location } \\
\cline { 2 - 3 } Parameter & Cepu age class III & Cepu age class VI \\
\hline DMg & $5.479^{\mathrm{t}}$ & $5.203^{\mathrm{t}}$ \\
$\mathrm{H}^{\prime}$ & 2.672 & 2.552 \\
$\mathrm{E}$ & $0.635^{\text {td }}$ & $0.604^{\mathrm{td}}$ \\
\hline
\end{tabular}

$\mathrm{t}=$ high, $\mathrm{td}=$ no species dominated, $\mathrm{H}^{\prime}=$ Shannon-Wiener's index of diversity,

$\mathrm{DMg}=$ Margalef's richness index and $\mathrm{E}=$ modified evenness index (Hill's ratio)

Table 3 Environmental condition in Cepu teak plantation

\begin{tabular}{lcc}
\hline & \multicolumn{2}{c}{ Location } \\
\cline { 2 - 3 } Variable of environmental factors & Cepu age class III & Cepu age class VI \\
\hline Temperature $\left({ }^{\circ} \mathrm{C}\right)$ & 28.40 & 28.40 \\
Relatif humidity $(\%)$ & 70.30 & 71.80 \\
$\mathrm{pH}$ & 6.60 & 7.10 \\
Cation exchange capacity (me $\left.100 \mathrm{~g}^{-1}\right)$ & 16.66 & 33.31 \\
Litter depth $(\mathrm{cm})$ & 6.55 & 6.90 \\
$\Sigma$ tree (individual) & 39.00 & 15.00 \\
$\Sigma$ understorey plant (individual) & 37.00 & 120.00 \\
Diversity of tree & 0.00 & 0.22 \\
Diversity of understorey plant & 1.93 & 1.20 \\
\hline
\end{tabular}


determining factor to the soil arthropods diversity and abundance (Bird et al. 2000; Bird et al. 2004). Forest litter in teak forest composed of dead plant part, including twigs and leafs. Wallwork (1976) stated that the thicker the litter, the more the food available for the arthropods. Litter quality is closely related with soil moisture to influence the soil arthropods (Costa et al. 2002). The litter with higher ratios of lignin/nitrogen and $\mathrm{C} / \mathrm{N}$ had higher diversity of Collembola (Pflug \& Wolters 2001). The thick litter could reflect a slower decomposition of leaves by microorganisms, which make large contributions to arthropods diets (Cortet \& PoinsotBalaguer 1998).

\section{Conclusion}

The H' of soil arthropods in the younger forest plantation was higher than that in the older one. This was attributed of high $\mathrm{E}$ and $\mathrm{R}$ indexs in young teak forest than the old one. The thickness of the litter of the young forest influenced the abundance of soil arthropods since the litter was the very important food source for survival of the soil arthropods. This study indicates that diversity of soil arthropods could be used as a preliminary information to understand the changes in the presence and abundance of the soil arthropods in the disturbed and virgin forest.

\section{Acknowledgements}

This work was supported by the Indonesian Ministry of Education through 'Hibah Bersaing' Research Fund. The authors would like to thank Perum Perhutani for their supporting and provision of field work.

\section{References}

Abbott I, Burbidge T, Strehlow K, Mellican A, Wills A. 2002. Logging and burning impacts on cockroaches, crickets and grasshoppers and spiders in Jarrah Forest, Western Australia. Forest Ecology and Management 174: 383-399. http://dx.doi.org/10.1016/S0378-1127(02) 00058-0.

Alato RV. 1981. Problem in the measurement of evenness in ecology. Oikos 37:199-204.

Alexander XA. 1997. Forest Health Monitoring Field Methods Guide (International 1995). North Caroline: USDA Forest Service Research Triangle Park.

Barbosa O, Marquet PA. 2002. Effects of forest fragmentation on the beetle assemblage at the relict forest of Fray Jorge, Chile. Oecologia 132:1-18. http://dx.doi.org/10.1007/s00442-002-0951-3.

Bird S, Coulson RN, Crossley Jr DA. 2000. Impacts of silvicultural practices on soil and litter arthropod diversity in a Texas pine plantation. Forest Ecology and Management 131:65-80. http://dx.doi.org/10. 1016/S0378-1127(99)00201-7.

Bird SB, Coulson RN, Fisher RF. 2004. Changes in soil and litter arthropod abundance following tree harvesting and site preparation in a loblollypine (Pinus taeda L.) plantation. Forest Ecology and Management 202:195208. http://dx.doi.org/10.1016/j.foreco. 2004.07.023.

Bluthgen $\mathrm{N}$ et al. 2000. How plants shape the ant community in the Amazonian rainforest canopy: the key role of extrafloral nectarines and homopterans honeydew. Oecologia 125: 229-240. http://dx.doi.org/ $10.1007 / \mathrm{s} 004420000449$.

Bolton B. 1997. Identification Guide to the Ant Genera of the World. London: Harvard University Press.

Bonham KJ, Mesibov R, Bashford R. 2002. Diversity and abundance of some ground-dwelling invertebrates in plantation vs. native forests in Tasmania, Australia. Forest Ecology and Management 158:237-247. http://dx.doi.org/10.1016/S0378-1127(00)00717-9.

Borror DJ, Charles AT, Norman FJ. 1996. Pengenalan Pelajaran Serangga. Partosoedjono S, translater. Yogyakarta: Gadjah Mada University Press. Translated from: An Introduction to the Study of Insect.

Cortet J, Poinsot-Balaguer N. 1998. Collembola populations under Sclerophyllous coppices in Provence (France): comparison between two types vegetation, Quercus ilex L. and Quercus coccifere L. Acta Oecologica 19(5):413-424. http://dx.doi.org/10. 1016/S1146-609X(98)80047-7.

Costa ES, Luizao FJ, Luizao RC, McMillan A. 2002. Litter layer dynamics and soil microbial biomass in reforested areas after degradation by bauxite mining in Eastern Amazon. In: Reddy MV, editor. Management of Tropical Plantation-Forests and Their Soil-Litter System. USA: Science Publishers.

DeBano LF, Neavy DG, Ffolliot PF. 1998. Fire's effects on ecosystem. New York: John Wiley \& Sons.

Deelman-Reinhold CL. 2001. Forest Spiders of South East Asia. Boston: Brill.

Detsis V, Diamantopoulos J, Kosmas C. 2000. Collembolan assemblages in Lesvos, Greece. Effects of difference in vegetation and precipitation. Acta Oecologica 21:149159. http://dx.doi.org/10.1016/S1146-609X(00)001107.

Dombos M. 2001. Collembola of loess grassland: effects of grazing and landscape on community composition. Soil Biology and Biochemistry 33:2037-2045. http://dx.doi. org/10.1016/S0038-0717(01)00125-0.

Fiala B, Maschwitz U, Pong TY, Helbig J. 1989. Studies of a South East Asian ant-plant association: protection of Macaranga trees by Crematogaster borneensis. Oecologia 79:463-470. http://dx.doi.org/10.1007 /BF00378662.

Finch OD. 2005. Evaluation of mature conifer plantations 
as secondary habitat for epigeic forest arthropods (Coleoptera: Carabidae; Araneae). Forest Ecology and Management 204:21-34. http://dx.doi.org/10.1016/j. foreco.2004.07.071.

Gandhi KK, Spence JR, Langor DW, Morgantini LE. 2001. Fire residuals as habitat reserves for epigaeic beetles (Coleoptera: Carabidae and Staphylinidae). Biological Conservation 102:131-141. http://dx.doi.org/10.1016/ S0006-3207(01)00099-4.

Gaston KJ. 1996. Biodiversity: a Biology of Numbers and Difference. London: Blackwell Science Ltd.

Goulet H, John TH. 1993. Hymenoptera of the World: An Identification Guide to Families. Canada: Agriculture Canada.

Hill JK, Hamer KC, Tangah J, Dawood M. 2001. Ecology of tropical butterflies in rainforest gaps. Oecologia 128 (2):294-302. http://dx.doi.org/10.1007/s0044201006 51 .

Idris AB, Hainidah J. 2003. Diversity of Ichneumonid wasps in the logged over forests of Langat Basin in Selangor, Malaysia. Journal of Biological Sciences 3: 259-270. http://dx.doi.org/10.3923/jbs.2003.259.270.

Idris AB, Nor-Zaneedarwarty N. 2000. The abundance and diversity of Braconidae in different habitats of Peninsular Malaysia. Journal of Bioscience 11: 41-77.

Jocque R, Dippenaar-Schoeman AS. 2005. Spider Families of the World. Afrika:ARC-PPRI .

Jukes MR, Peace AJ, Ferris R. 2001. Carabid beetle communities associated with coniferous plantations in Britain: the influence of site, ground vegetation and stand structure. Forest Ecology and Management 148: 271-286. http://dx.doi.org/10.1016/S0378-1127(00) 00530-2.

Ludwig JA, Reynolds JF. 1988. Statistical ecology: A Primer Methods and Computing. New York: John Wiley $\&$ Sons.

Magura T. 2002. Carabid and forest edge. Forest Ecology and Management 157:23-37. http://dx.doi.org/ 10.1016/S0378- 1127(00)00654-X.

Magurran AE. 1988. Ecological Diversity and Its Measurement. London: Croom Helm Ltd.

Majer JD, Nichols OG. 1998. Long term recolonization pattern of ants in Western Australia rehabilitated bauxite mines with reference to their use as indicators of restoration success. Journal of Applied Ecology 35: $161-182$

Malsch AKF, Rosciszewski K, Maschwitz U. 2003. The ant species richness and diversity of a primary lowland rain forest, the Pasoh Forest Reserve, West-Malaysia. Pp
347-373 in Okuda T et al., editors. Pasoh: Ecology of a Lowland Rain Forest in Southeast Asia. Tokyo: Springer.

Manh VQ, Nguyen TT. 2000. Microarthropod community structures (Oribatei and Collembola) in Tam Dao National Park, Vietnam. Journal of Biosciences 25: 379-386. http://dx.doi.org/10.1007/BF02703791.

Maschwitz U, Fiala B, Davies ST, Linsenmair KE. 1996. A Southeast Asian Myrmecophyte with two alternative inhabitants: Camponotus or Crematogaster as partners of Macaranga lamellate. Ecotropica 2: 29-40.

Orendt C. 2000. The chironomid communities of woodland springs and spring brooks, severely endangered and impacted ecosystems in a lowland region of Eastern Germany (Diptera: Chironomidae). Journal of Insect Conservation 4(2):79-91. http://dx.doi.org/10. 1023/A: 1009684015564

Pflug A, Wolters V. 2002. Collembola communities along a European transect. European Journal of Soil Biology 38: 301-304. http://dx.doi.org/10.1016/S1164-5563(02) 01163-9.

Retana J, Cerda X. 2000. Patterns of diversity and composition of Mediterranean ground ant communities tracking spatial and temporal variability in the thermal environment. Oecologia 123:436-444. http://dx.doi.org/10.1007/s004420051031.

Samways M J. 1994. Insect Conservation Biology. London: Chapman and Hall.

Siira-Pietikainenm A, Haimi J, Siitonen J. 2003. Short-term responses of soil macroarthropod community to clear felling and alternative forest regeneration methods. Forest Ecology and Management 172:339-353. http://dx.doi.org/10.1016/S0378-1127(01)00811-8.

Siira-Pietikainenm A, Pietikainen J, Fritze H, Haimi J. 2001. Short-term responses of soil decomposer communities to forest management: clear felling versus alternative forest harvesting methods. Canadian Journal of Forest Research 32: 88-99.

Strehlow K, Bradley JS, Davis J, Friend GR. 2002. Short term impacts of logging on invertebrate communities in jarrah forests in south-west Western Australia. Forest Ecology and Management 162: 165-184. http://dx.doi.org/10.1016/S0378-1127(01)00504-7.

Toft RJ, Harris RJ, Williams PA. 2001. Impacts of the weed Tradescantia fluminensis on insect communities in fragmented forests in New Zealand. Biological Conservation 102:31-46. http://dx.doi.org/10. 1016/ S0006-3207(01)00091-X.

Wallwork JA. 1976. The Distribution and Diversity of Soil Fauna. San Fransisco: Academi Press. 
Ward DF, New TR, Yen AL. 2001. Pitfall in effect of spacing for abundance, richness and composition on surface invertebrates. Journal of insect Conservation 5(1):47-53. http://dx.doi.org/10.1023/A:1011317 423622 .

Warren MW, Zou X. 2002. Soil macrofauna and litter nutrients in three tropical tree plantations on a disturbed site in Puerto Rico. Forest Ecology and Management 170:161-171. http://dx.doi.org/10.1016/S0378-1127 (01)00770-8.

Zhu I, Matsuzaki T, Sakioka K. 2000. Wind speeds within a single crown of Japanese black pine (Pinus thunbergii Parl.). Forest Ecology and Management 135:19-31. http:// dx.doi.org/10.1016/S0378-1127(00)00295-4 12(2):64-69. 